\begin{tabular}{|l|l|l|}
\hline \multicolumn{2}{|c|}{ PublisherInfo } \\
\hline \hline PublisherName & $:$ & BioMed Central \\
\hline \hline PublisherLocation & $:$ & London \\
\hline \hline PublisherImprintName & $:$ & BioMed Central \\
\hline \hline
\end{tabular}

\title{
Diabetic ketoacidosis and bicarbonate therapy
}

\begin{tabular}{|l|l|l||}
\hline \multicolumn{2}{|c|}{ ArticleInfo } \\
\hline \hline ArticleID & $:$ & 4251 \\
\hline \hline ArticleDOI & $:$ & $10.1186 /$ ccf-2000-4308 \\
\hline \hline ArticleCitationID & $:$ & 4308 \\
\hline \hline ArticleSequenceNumber & $:$ & 39 \\
\hline \hline ArticleCategory & $:$ & Paper Report \\
\hline ArticleFirstPage & $:$ & 1 \\
\hline \hline ArticleLastPage & $:$ & 3 \\
\hline \hline & & RegistrationDate : 2000-2-10 \\
\hline ArticleHistory & $:$ & OnlineDate \\
\hline \hline ArticleCopyright & $:$ & Current Science Ltd2000-2-10 \\
\hline \hline ArticleGrants & $:$ & \\
\hline \hline ArticleContext & $:$ & 1305433 \\
\hline \hline
\end{tabular}




\section{Keywords}

Bicarbonate, diabetes, diabetic ketoacidosis

\section{Comments}

The retrospective nature of this study limits the conclusions that can be drawn about alkalinisation therapy in patients with severe diabetic ketoacidosis (DKA). The opportunity for a randomised, controlled trial for bicarbonate therapy in patients with $\mathrm{pH}<7.1$ will be very appealing to many readers of this study. The authors also comment that the treatment of patients with $\mathrm{pH}<6.9$ may require alkalinisation, but again the clinical evidence is lacking from this more severe group.

\section{Introduction}

Many patients with severe DKA receive bicarbonate when their arterial $\mathrm{pH}$ falls below 7.10. The benefits of bicarbonate therapy include improved myocardial function, decreased vasodilation and a reduction in the incidence of ventricular arrhythmias. However, bicarbonate therapy is not without adverse effects, including hypokalaemia, ionized hypocalcaemia, paradoxical acidosis in the central nervous system and an increased haemoglobin/oxygen affinity (leading to peripheral tissue hypoxia).

\section{Aims}

To assess the efficacy of bicarbonate therapy in adult patients with severe DKA.

\section{Methods}

This retrospective study examined the records of all patients with DKA admitted to the emergency department of a university hospital over a 5 -year period. Those patients with an arterial $\mathrm{pH}<7.10$, blood glucose $>15 \mathrm{mmol} / \mathrm{l}$ and urinary ketones $>+++$ on the reagent stick were included in the study and 
analysed according to whether or not they received bicarbonate therapy. The hospital had established precise recommendations for the management of DKA, which had been instituted before the start of the study. These recommendations provided a protocol for insulin and fluid infusion, but bicarbonate therapy was not covered by the guidelines (being prescribed by the individual physician).Outcome measures (including clinical and biochemical parameters) were compared between patients receiving or not receiving bicarbonate therapy, using either $\chi^{2}$ test or a Student's $t$-test.

\section{Results}

Thirty-nine patients were included in this study, of whom 24 received bicarbonate and 15 did not. There was no statistical difference in the admission, biochemical and clinical scores. Mean $\mathrm{pH}$ was 6.93 \pm 0.13 in the bicarbonate group and $7.0 \pm 0.08$ in the non-bicarbonate group. The patients receiving bicarbonate received $88-166 \mathrm{mEq}$ of sodium bicarbonate. Time to $\mathrm{pH}$ normalisation and urinary ketone clearance was the same in both groups. The bicarbonate group received a greater potassium supplementation than the non-bicarbonate group. There were no other differences in the measured biochemical or clinical parameters. There were no fatal outcomes in either group.

\section{Discussion}

The authors highlight how, in recent years, the management of diabetic patients has been well established with regard to doses and route of insulin administration and rehydration. Despite no existing data demonstrating the beneficial effects of bicarbonate therapy, this is frequently recommended for patients with an arterial $\mathrm{pH}$ of $<7.00$. The authors comment that, in their study, the administration of bicarbonate to patients with severe DKA does not produce a more rapid normalisation of biochemical or clinical parameters. The authors state that, although this study is limited by its retrospective nature, the results have induced them to stop using bicarbonate in patients with severe DKA.

\section{References}

1. Viallon A, Zeni F, Lafond P, Venet C, Tardy B, Page Y, Betrand J-C: Does bicarbonate therapy improve the management of severe diabetic ketoacidosis?. Crit Care Med. 2000, 27: 2690-2693.

This PDF file was created after publication. 